Marquette University

e-Publications@Marquette

Biological Sciences Faculty Research and

Publications

Biological Sciences, Department of

2-2017

\title{
Physiological Regulation and Efficient Xylem Water Transport Regulate Diurnal Water and Carbon Balances of Tropical Lianas
}

\author{
Ya-Jun Chen \\ Chinese Academy of Sciences \\ Stefan A. Schnitzer \\ Marquette University, stefan.schnitzer@marquette.edu \\ Yongg-Jiang Zhang \\ Chinese Academy of Sciences \\ Ze-Xin Fan \\ Chinese Academy of Sciences \\ Guillermo Goldstein \\ University of Miami
}

See next page for additional authors

Follow this and additional works at: https://epublications.marquette.edu/bio_fac

Part of the Biology Commons

\section{Recommended Citation}

Chen, Ya-Jun; Schnitzer, Stefan A.; Zhang, Yongg-Jiang; Fan, Ze-Xin; Goldstein, Guillermo; Tomlinson, Kyle W.; Lin, Hua; Zhang, Jiao-Lin; and Cao, Kun-Fang, "Physiological Regulation and Efficient Xylem Water Transport Regulate Diurnal Water and Carbon Balances of Tropical Lianas" (2017). Biological Sciences Faculty Research and Publications. 569.

https://epublications.marquette.edu/bio_fac/569 


\section{Authors}

Ya-Jun Chen, Stefan A. Schnitzer, Yongg-Jiang Zhang, Ze-Xin Fan, Guillermo Goldstein, Kyle W. Tomlinson, Hua Lin, Jiao-Lin Zhang, and Kun-Fang Cao

This article is available at e-Publications@Marquette: https://epublications.marquette.edu/bio_fac/569 
Marquette University

e-Publications@Marquette

Biology Faculty Research and Publications/College of Arts and Sciences

This paper is NOT THE PUBLISHED VERSION; but the author's final, peer-reviewed manuscript. The published version may be accessed by following the link in th citation below.

Functional Ecology, Vol. 31, No. 2 (February 2017): 306-317. DOI. This article is (C British Ecological Society and permission has been granted for this version to appear in e-Publications@Marquette. British Ecological Society does not grant permission for this article to be further copied/distributed or hosted elsewhere without the express permission from British Ecological Society.

\section{Physiological Regulation and Efficient Xylem Water Transport Regulate Diurnal Water and Carbon Balances of Tropical Lianas}

\section{Ya-Jun Chen}

Key Laboratory of Tropical Forest Ecology, Xishuangbanna Tropical Botanical Garden, Chinese Academy of Sciences, Mengla, Yunnan, 666303 China University of Chinese Academy of Sciences, Beijing, 100049 China

Stefan A. Schnitzer

Department of Biological Sciences, Marquette University, PO Box 1881, Milwaukee, WI, Yong-Jiang Zhang

Key Laboratory of Tropical Forest Ecology, Xishuangbanna Tropical Botanical Garden, Chinese Academy of Sciences, Mengla, Yunnan, 666303 China

Ze-Xin Fan

Key Laboratory of Tropical Forest Ecology, Xishuangbanna Tropical Botanical Garden, Chinese Academy of Sciences, Mengla, Yunnan, 666303 China

Guillermo Goldstein

Department of Biology, University of Miami, PO Box 249118, Coral Gables, FL, 


\section{Kyle W. Tomlinson}

Center for Integrative Conservation, Xishuangbanna Tropical Botanical Garden, Chinese Academy of Sciences, Mengla, Yunnan, 666303 China

\section{Hua Lin}

Key Laboratory of Tropical Forest Ecology, Xishuangbanna Tropical Botanical Garden, Chinese Academy of Sciences, Mengla, Yunnan, 666303 China

\section{Jiao-Lin Zhang}

Key Laboratory of Tropical Forest Ecology, Xishuangbanna Tropical Botanical Garden, Chinese Academy of Sciences, Mengla, Yunnan, 666303 China

\section{Kun-Fang Cao}

Key Laboratory of Tropical Forest Ecology, Xishuangbanna Tropical Botanical Garden, Chinese Academy of Sciences, Mengla, Yunnan, 666303 China

State Key Laboratory for Conservation and Utilization of Subtropical Agro - bioresources, Guangxi University, Nanning, Guangxi, 530004 China

\section{Summary}

1. Tropical lianas deploy most of their leaves towards the top of the forest canopy, whereas trees exhibit a more stratified crown. Forest canopies are often exposed to hot and windy conditions, and how lianas cope with the extremely high transpirational demands under these environments remains unknown.

2. We investigated stem hydraulic properties, leaf drought tolerance, diurnal changes in leaf and stem water potentials ( $\Psi_{\text {leaf }}$ and $\left.\Psi_{\text {stem }}\right)$, stomatal conductance $\left(g_{\mathrm{s}}\right)$, photosynthetic rate, sap flow and stem native percentage loss of conductivity (PLC) for four liana species in a tropical forest in southwest China. Five co-occurring tree species were also selected for comparison.

3. Lianas reached maximal transpiration at a relatively lower vapour pressure deficit $(<1 \mathrm{kPa})$ than did cooccurring trees, suggesting vigorous photosynthesis during the morning. However, liana $g_{\mathrm{s}}$ declined markedly over the day, with low $g_{\mathrm{s}}$ at midday and afternoon. Lianas generally had higher stem sapwoodspecific conductivity and maximum sap flux density but were less tolerant to drought-induced cavitation than were evergreen trees. Both lianas and trees lost leaf turgor in the top canopy at midday, but lianas lost leaf turgor earlier ( $\sim 2 \mathrm{~h})$ than trees.

4. Seven of eight species exhibited midday increases in PLC when xylem tensions were released to $-0 \cdot 3$ to $-0.5 \mathrm{MPa}$ for PLC measurements. On average, lianas experienced high PLC (35.9\%), along with a greater degree of disequilibrium between leaf and stem water potentials than trees ( $\Delta \Psi_{\text {stem-leaf: }} 1.37 \mathrm{MPa}$ vs. $0.75 \mathrm{MPa}$ ) during the day. Earlier stomatal closure and efficient water transport may help lianas maintain higher $\Psi_{\text {stem }}$ than trees despite having similar $\Psi_{\text {leaf. }}$

5. Our results provide evidence that physiological regulation and efficient water transport mediate daily water relations in tropical lianas and may explain how lianas operate efficiently in tropical seasonal forests. Further studies involving a broader range of species are needed to confirm our findings.

\section{Introduction}

Canopy plants in seasonal tropical forests experience water deficits both during the dry season, when soil water is depleted, and during the wet season, when plants are exposed to high transpirational demands at midday. Transpiration-induced water deficits (low water potentials) can result in a strong downregulation of stomatal conductance and thus a reduction in leaf carbon gain (Simonin et al. 2015). Midday decline in photosynthesis, 
stomatal conductance and leaf-specific conductance have been observed in many plant species regardless of soil water status (Brodribb \& Holbrook 2003, 2004; Bunce 2006; Chapotin, Razanameharizaka \& Holbrook 2006; Tucci et al. 2010; Zufferey et al. 2011; Cao et al. 2012; Yang et al. 2012; Zhang et al. 2013; Hacke 2014). Midday reduction in leaf photosynthetic performance in response to daily water deficits reflects a trade-off between carbon fixation and hydraulic safety.

Plants depend on several different physiological adaptations that facilitate rapid response to changes in soil water availability and vapour pressure deficits (VPDs). For instance, leaf stomatal regulation plays a critical role in the balance between water loss and carbon fixation (McDowell et al. 2008); by regulating the stomatal aperture, plants can limit water loss and thus maintain xylem tension within a safe range, reducing the risks of xylem dysfunction (Brodribb \& Holbrook 2003; Brodribb et al. 2003; Bucci et al. 2003; Johnson et al. 2011). Stomatal regulation can be governed by leaf and stem water potentials, VPD and ABA content (Comstock \& Mencuccini 1998; Salleo et al. 2000; Brodribb et al. 2003; Bunce 2006; Chapotin, Razanameharizaka \& Holbrook 2006; Tucci et al. 2010; Scoffoni et al. 2012; Zhang et al. 2013). Rapid stomatal response to the increases in transpirational demands reduces the risk of excessive dehydration and irreversible hydraulic dysfunction (i.e. embolism) in the vascular system; stomatal regulation thus represents an especially important adaptation for canopy plants, which frequently experience high transpirational demands. Stomatal regulation may be particularly important for lianas compared with their host trees, because lianas have a higher proportion of exposed leaves at the top of the canopy, where transpirational demand is higher (Putz 1983), and their internal stem water storage is comparatively small (Chen et al. 2016a).

Lianas are an important component of tropical and subtropical forests, contributing up to $35 \%$ of woody plant diversity and 40\% of stem density (Gerwing \& Farias 2000; Chave, Riera \& Dubois 2001; Schnitzer \&

Bongers 2002, 2011); they are considered to be structural parasites because they commonly use the stems of other plants (mostly trees) to ascend to the forest canopy (Schnitzer \& Bongers 2002). As a consequence, lianas may have a higher proportion of photosynthetic biomass per whole-plant biomass (Wyka et al. 2013). Trees tend to have larger internal stem water storage than lianas, enabling trees to use water stored in the top portion of their trunk to replace water lost through transpiration, whereas lianas rely primarily on soil water (Chen et al. 2016a). Exposure to the stressful environment of the upper forest canopy does not prevent lianas from colonizing the canopy; rather, lianas typically form a carpet-like leafy layer in the uppermost canopy in many tropical forests. Lianas generally have wider and longer vessels than trees and are reported to be hydraulically efficient but vulnerable to drought-induced cavitation (Isnard \& Silk 2009; Zhu \& Cao 2009; Johnson et al. 2013; Chen et al. 2014). The mechanism by which lianas balance hydraulic efficiency with safety and the role of stomatal regulation are both poorly understood, but may be key to explaining how lianas aggressively colonize both treefall gaps and seasonally dry forests (Schnitzer 2005; Ledo \& Schnitzer 2014).

Here, we examined the stem hydraulic properties, leaf drought tolerance, diurnal variations in photosynthesis and leaf stomatal conductance, leaf and stem water potentials and sap flow of four tropical lianas in southwestern China. In addition, we measured the same physiological properties for five co-occurring trees (two deciduous and three evergreen trees) for the purposes of comparison with lianas. Our goal was to determine how tropical lianas cope with the extremely high transpirational demands prevalent in forest canopies. Specifically, we tested whether physiological regulation aids lianas in mediating diurnal water and carbon balances. 


\section{Materials and methods}

\section{Field site}

The study was conducted at Xishuangbanna Tropical Botanical Garden (XTBG, $21^{\circ} 54^{\prime} \mathrm{N}, 101^{\circ} 46^{\prime} \mathrm{E}, 580 \mathrm{~m}$ a.s.l.), Chinese Academy of Sciences in south of Yunnan Province, China. A $30 \times 30 \mathrm{~m}$ plot located in a natural flood plain forest inside XTBG was selected for the study. This region has a distinct dry season from November to April. Mean annual precipitation is approximately $1560 \mathrm{~mm}$, nearly $80 \%$ of which occurs during the wet season from May to October. Mean annual temperature is $21.7^{\circ} \mathrm{C}$ with a monthly mean temperature of $15.9^{\circ} \mathrm{C}$ in the coldest month (December) and $25.7^{\circ} \mathrm{C}$ in the hottest month (June). We used meteorological data recorded at 30-min intervals (photosynthetic photon flux density (PPFD), air temperature, relative humidity) from a weather station (Xishuangbanna Tropical Rainforest Ecosystem Station of the Chinese Academy of Sciences) located $1 \mathrm{~km}$ away from our study site.

\section{Diurnal change in photosynthesis, stomatal conductance and leaf and stem water potentials}

We selected nine species (three individuals per species) in total, consisting of four liana species (Celastrus paniculatus, Mucuna interrupta, Marsdenia sinensis and Ventilago calyculata) and five tree species (Celtis tetrandra, Ficus concinna, Harpullia cupanioides,Michelia hypolampra and Streblus asper) for quantification of the gas exchange parameters: photosynthetic rate $\left(P_{n}\right)$ and stomatal conductance $\left(g_{s}\right)$. Measurements were conducted at 2-h intervals between 08:00 and 18:00 over five clear days between 8 and 21 October 2012. Access to the forest canopy was attained through the use of a truck crane. Six sun-exposed leaves from three individuals per species were marked prior to the gas exchange measurements to ensure that all diurnal course measurements were made on the same leaves. Gas exchange was measured using an open-flow gas exchange

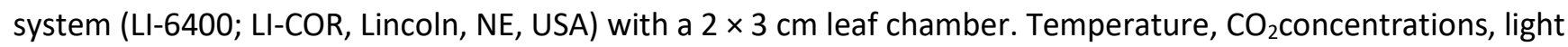
and humidity in the leaf chamber were the same ambient environmental conditions. The rate of air flow rate through the leaf chamber was set to $500 \mu \mathrm{mol} \mathrm{s}^{-1}$. Measurements were logged once the rate of gas exchange stabilized. Finally, leaf stomatal conductance was plotted against the chamber VPD.

For each species, six fully expanded new leaves from neighbouring sun-exposed terminal branches were selected for measurement of leaf water potential ( $\left.\Psi_{\text {leaf }}\right)$ concurrently with the gas exchange measurements. Leaf samples were cut with a razorblade and sealed in plastic bags containing moistened paper towels, then kept in a cold box for 20 min to attain a balancing pressure. Water potential of the samples was obtained using a pressure chamber (PMS1000; PMS Instrument Company, Corvallis, OR, USA). Stem water potential ( $\left.\Psi_{\text {stem }}\right)$ was estimated by measuring the water potential of a non-transpiring leaf. Six sun-exposed leaves were sealed in plastic bags and covered with aluminium foil the previous evening for the $\Psi_{\text {stem }}$ measurements. All measurements were completed in situ within $1 \mathrm{~h}$ following leaf excision.

\section{Maximum vessel length and stem hydraulic measurements}

The maximum vessel length (MVL) was measured using the air-injection method (Ewers \& Fisher 1989) before performing stem hydraulic property measurements. Ten branches from four individuals per species were cut for use in the MVL quantification. The apex end ( $\approx 5 \mathrm{~mm}$ in diameter) of each stem was cut and connected to a tube connected to $100-\mathrm{kPa}$ compressed nitrogen gas, with the distal end immersed in water. The stem was shortened at $1 \mathrm{~cm}$ intervals successively until the first bubble emerged, with MVL defined as the amount to the remaining stem length plus $0.5 \mathrm{~cm}$.

Maximum stem sapwood-specific conductivity $\left(K_{\mathrm{s}-\mathrm{max}}, \mathrm{kg} \mathrm{m}^{-1} \mathrm{~s}^{-1} \mathrm{MPa}^{-1}\right)$ was determined using a hydraulic conductivity measurement system, as described by Sperry, Donnelly \& Tyree (1988), during July and October 2014. Briefly, a total of 10-12 segments (ca. 1.5 times the length of MVL) per species were cut before sunrise, 
placed in black plastic bags and then transported to the laboratory within $1 \mathrm{~h}$. Stem segments were then trimmed to lengths ca. $10 \%$ longer than MVL underwater. Each stem segment was flushed with degassed ultrafiltered $10 \mathrm{~mm} \mathrm{KCl}$ solution at pressures of $100 \mathrm{kPa}$ for about $30 \mathrm{~min}$ to remove emboli. Flushed segments were subsequently connected to a pressure head $(\sim 5 \mathrm{kPa})$ containing the same filtered $\mathrm{KCl}$ solution as above. The distal end of each segment was connected with a pipette to obtain a flushed flow rate, and the maximum stem sapwood-specific conductivity was calculated as follows:

$$
K_{\mathrm{S}-\max }=F L /\left(\Delta P A_{\text {sw }}\right) ;(\text { eqn } 1)
$$

$$
K_{s-\max }=F L /\left(\Delta D P A_{s \mathrm{w}}\right)
$$

where $F$ is the flow rate $\left(\mathrm{kg} \mathrm{s}^{-1}\right), L$ is the stem length $(\mathrm{m}), \Delta P$ is the driving force (MPa) and $A_{s w}\left(\mathrm{~m}^{2}\right)$ is the crosssectional area of the active xylem.

We measured vulnerability curves (VCs) using the bench dehydration method (Sperry, Donnelly \& Tyree $\underline{1988}$ ) for six of the bine species. An air-injection method (Cochard, Cruiziat \& Tyree 1992) was used to determine the VCs of two latex-containing tree species (S. asper and F. concinna). We did not measure the hydraulic properties (VCs and native percentage loss of conductivity) for the liana $M$. interrupta because the terminal branches of this species were too thin (commonly $<3 \mathrm{~mm}$ in diameter) to conduct measurement (Appendix S1, Supporting Information).

\section{Native stem sapwood-specific conductivity and diurnal percentage loss of conductivity} Several recent studies have shown that the diurnal percentage loss of conductivity (PLC) and recovery cycles previously reported in the literature could be artefacts of sample preparation or measurement methodologies (Cochard \& Delzon 2013; Torres-Ruiz et al. 2014; Wang et al. 2014; Zhang \& Holbrook 2014). Wheeler et al. (2013) reported that the high PLC values and subsequent repairing observed in red maple and white ash trees were actually simple due to sampling under tension and that there was no significant difference in PLC between pre-dawn and midday if tension was relaxed prior to hydraulic measurements. Direct X-ray microtomography (Torres-Ruiz et al. 2015) also confirmed that high PLC values are artefacts of stems cut while under tension. In contrast, tension-cutting effects are not found in other studies (Trifilò et al. 2014; Venturas, MacKinnon \& Jacobsen 2014; Scoffoni \& Sack 2015). Trifilò et al. (2014) and Venturas, MacKinnon \& Jacobsen (2014) suggest that relaxation procedures favour embolism repairs and thus lead to underestimations of PLC values.

We conducted tension-relaxation procedures (1-2 h) similar to those described by Wheeler et al. (2013) 1-2 h prior to all native PLC measurement because we believed that cavitation refilling could not occur in detached branches in such a relatively short time. We avoided long time relaxation ( $>2 \mathrm{~h}$ ) to prevent embolism refilling by capillary pressure (Torres-Ruiz et al. 2015). We measured the native PLC on sunny days during May and June 2014. Pre-dawn samples were collected between 05:30 and 06:30 before sunrise, whereas midday samples were collected between 13:00 and 15:00. To avoid cutting effects like those mentioned above, we collected branches of lengths that would ensure that segments were at least double the length of the MVL for each species. All branches were cut from the canopy, with the cut ends wrapped in parafilm (Parafilm M; Bemis Inc., Oshkosh, WI, USA) to reduce water loss. Each branch was sprayed with water to maintain wetness and then enclosed in a black plastic bag $(1.5 \mathrm{~m} \times 1.5 \mathrm{~m})$. For liana species, nearly all leaves were located on the top of the branches, so only top stem segments with leaves were bagged. Samples were brought to the laboratory within 30 min of excision, and water was sprayed on the branches every 3-5 min to minimize desiccation. All samples were recut underwater in the laboratory (to remove ca. $40 \mathrm{~cm}$ in length), then kept in darkness for 1-2 $\mathrm{h}$ to release tension in the xylem conduits (Wheeler et al. 2013). Celastrus paniculatus and V. calyculata were 
selected for determination of xylem tension based on preliminary research, which revealed that the two species exhibit high midday PLC. Changes in leaf water potential were recorded at 30-min intervals over the first 2-h rehydration; leaf water potentials after $1 \mathrm{~h}$ of rehydration ranged from $-0.3 \mathrm{MPa}$ to $-0.5 \mathrm{MPa}$ (see Fig. S1). The remaining stem was recut (to remove 1.5 times $\mathrm{MVL}$ in length, which was used to determine $K_{\mathrm{s} \text {-max }}$ following Eqn eqn 1) underwater. The targeted stem segment (ca. 20-cm length) was cut for the determination of PLC as follows:

$$
\begin{aligned}
& \text { PLC }=100 \times\left(K_{\max }-K_{0}\right) / K_{\max }(\text { eqn 2) } \\
& \qquad \mathrm{PLC}=100 \times\left(K_{\max }-K_{0}\right)=K_{\max } ;
\end{aligned}
$$

where $K_{0}$ and $K_{\max }$ were the actual and maximum hydraulic conductance, respectively.

The native stem sapwood-specific conductivity $\left(K_{\mathrm{s}}, \mathrm{kg} \mathrm{m}^{-1} \mathrm{~s}^{-1} \mathrm{MPa}^{-1}\right)$ was calculated as follows:

Native $K_{\mathrm{s}}=K_{\mathrm{S}-\max } \times(1-\mathrm{PLC}) \cdot($ eqn 3)

$$
\text { Native } K_{\mathrm{s}}=K_{\mathrm{s}-\max } \times(1-\mathrm{PLC})
$$

Seven of the eight liana and tree species exhibited significant midday increases in PLC compared to pre-dawn, indicating that rehydrating the samples for 1-2 $\mathrm{h}$ to ca. $-0.4 \mathrm{MPa}$ probably does not refill xylem embolisms, as was suggested by Trifilò et al. (2014) and Venturas, MacKinnon \& Jacobsen (2014). It is possible that species with large vessels are prone to cutting artefacts even when xylem tensions are as low as ca. $-0.4 \mathrm{MPa}$. It is unknown whether the cutting under tension artefact is xylem tension-dependent, but the magnitude of the artefact is species-dependent (Wheeler et al. 2013). Therefore, the given species may have some structural properties (e.g. vessels) that require full relaxation (i.e. $0 \mathrm{MPa}$ ) to avoid cutting artefacts. However, relaxation to $0 \mathrm{MPa}$ may cause embolism refilling by capillary pressure, which would confound the results and complicate PLC analyses (Torres-Ruiz et al. 2015). Many uncertainties in explaining observed diurnal PLC patterns remain, and further research involving more direct measurements, such as X-ray microtomography, are needed to resolve the current controversies.

\section{Leaf pressure-volume curves}

Pressure-volume (P-V) curves were determined for 10-12 mature leaves from three individuals using the bench dehydration technique described by Lenz, Wright \& Westoby (2006). Terminal branches were cut under water and then rehydrated overnight to ensure that $\Psi_{\text {leaf }}>-0.1 \mathrm{MPa}$. Leaf fresh mass and $\Psi_{\text {leaf }}$ were measured

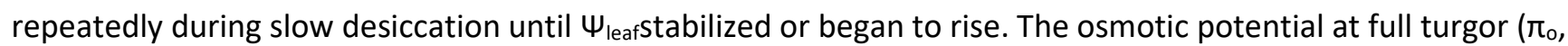
$\mathrm{MPa})$, the turgor loss point ( $\left.\pi_{\mathrm{t} \mid \mathrm{p}}, \mathrm{MPa}\right)$, the bulk modulus of elasticity $(\varepsilon, \mathrm{MPa})$ and absolute capacitance $\left(C_{\text {leaf, }}\right.$ $\mathrm{mol} \mathrm{m}^{-2} \mathrm{MPa}^{-1}$ ) were calculated following procedures described by Sack, Pasquet-Kok \& contributors, P. (2011). A few oversaturated samples, detected by a plateau in the initial P-V curves, were discarded.

\section{Sap flow}

Sap flow was monitored during the end of the wet season (8-21 October 2012). We measured sap flow for all nine species (three to five individuals per species) mentioned above (data for the tree Ficus concinna were excluded because the sap-flow sensors were broken down during measurement). The diameter at breast height was greater than $5 \mathrm{~cm}$ for lianas and 10-60 cm for trees. Sap flow was measured using 20-mm-length thermal dissipation sensors with two probes, as described by Granier (1987). Sensors were inserted into the stems $1.3 \mathrm{~m}$ above the ground for trees and $1.3 \mathrm{~m}$ from the last rooting points for lianas and covered with reflective material to avoid temperature effects from direct radiation. We measured light intensity using a light meter (QRT1; 
Hansatech Instruments, Norfolk, UK) and determined that the light intensity at heights of $1.3 \mathrm{~m}$ above the ground average about 1-2\% that of full light. We ignored temperature gradients over the course of the day. The differences in temperature between two probe needles of a sensor $(\Delta T)$ were monitored every $30 \mathrm{~s}$, with 10-min averages recorded with a datalogger (CR1000; Campbell Scientific, Logan, UT, USA) connected to a 32-channel multiplexer (AM16/32). The $\Delta T$ between the heated and reference probes were converted to sap flux density $\left(\mathrm{g} \mathrm{m}^{-2} \mathrm{~s}^{-1}\right)$ based on the following equation:

$$
\begin{aligned}
& J_{\mathrm{s}}=119 \times\left(\left(\Delta T_{\max }-\Delta T\right) / \Delta T\right)^{1 \cdot 231} \text { (eqn 4) } \\
& J_{\mathrm{s}}=119 \times\left(\left(\Delta T_{\max }-\Delta T\right) / \Delta T\right)^{1 \cdot 231},
\end{aligned}
$$

where $\Delta T_{\max }$ represents the temperature difference between the heated and reference probes when sap flux is zero. We assume that zero sap flow could be achieved during the night because of low nocturnal air VPD in the wet season. In a preliminary study of 29 individuals, we found time lags between base and canopy sap flow for only two trees $(<30 \mathrm{~min}$ ) and one liana individual $(<10 \mathrm{~min}$ ) during the wet season, so we used base sap flow to represent canopy transpiration. The daily hourly averages of $J_{s}$ were plotted against concurrent ambient VPD to show how $J_{s}$ responds to increasing VPD in lianas and trees. Concurrent VPD values were calculated using air temperature and humidity.

We recorded the maximum sap flow on a given day, $J_{\max }$. We defined start time of sap flow as the time when $J_{s}$ rises to $10 \%$ of $J_{\max }$ in the morning, start time of peak sap flow as the time when $J_{\mathrm{s}}$ rises to $80 \%$ of $J_{\max }$ and daily peak sap-flow interval as the time during which $J_{s}$ is above $80 \%$ of $J_{\max }$. We defined sap-flow response time as the time interval when $J_{s}$ rises from $10 \%$ to $80 \%$ of $J_{\max }$.

\section{Data analysis}

We calculated species mean values for MVL, $K_{\mathrm{s}-\max }$, water potential at $50 \%$ loss of conductivity $\left(P_{50}, \mathrm{MPa}\right)$, midday PLC and $K_{\mathrm{s}}, \mathrm{P}-\mathrm{V}$ parameters, $J_{\max }$, duration of daily peak sap flow and sap-flow response time. All response variables were tested for normality and natural log or square-root transformed when necessary. We compared the differences in the means between lianas and trees using Student's $t$-tests. We also extended these analyses to consider the differences among three groups (lianas, deciduous trees and evergreen trees) using one-way anova and post hoc tests with Bonferroni corrections. All group comparisons were conducted using SPSS version 16.0 software (SPSS, Chicago, IL, USA).

We tested whether the relationships between $g_{\mathrm{s}}$ and each of three predictors - leaf water potential, xylem water potential and VPD - differed between lianas and trees using a mixed model, with species treated as the random effect. Both random slopes and random intercepts were included in the initial model, but random slopes were excluded from the final model because likelihood ratio tests determined that they did not explain significant variation in the data. Significance of the fixed effects was also examined using likelihood ratio tests, and non-significant effects were removed using backward selection with likelihood ratio tests, These analyses were conducted using the Imer() function of Ime4 in r (Bates et al. 2015).

\section{Results}

\section{Stem and leaf hydraulic properties}

Maximum vessel length varied greatly among the species, ranging from 110 to $301 \mathrm{~cm}$ in lianas and from 61 to $192 \mathrm{~cm}$ in trees (Table 1). Mean MVL of lianas was more than twice that of trees; however, the difference in MVL was not statistically significant between the two groups due to the high interspecific variance within 
growth forms. Similarly, liana and tree species differed in $K_{\text {s-max }}$ but not in $P_{50}$; lianas had higher $K_{\mathrm{s}-\max }$ and $P_{50}$ than the three evergreen tree species $\left(K_{\mathrm{s}-\mathrm{max}}: 8.0 \mathrm{vs.} 1.9 \mathrm{~kg} \mathrm{~m}^{-1} \mathrm{~s}^{-1} \mathrm{MPa}^{-1}, P<0.05 ; P_{50}:-1.34 \mathrm{MPa}\right.$ vs.

$-2.56 \mathrm{MPa}, P=0.055$; Fig. 1 and Table S1), but these values did not differ from those of the two deciduous trees ( $K_{\text {s-max: }}: 8.0$ vs. $5.1 \mathrm{~kg} \mathrm{~m}^{-1} \mathrm{~s}^{-1} \mathrm{MPa}^{-1} ; P_{50}:-1.48 \mathrm{MPa}$ vs. $-1.34 \mathrm{MPa}$; see Table S1). Leaf drought tolerance was comparable in lianas and trees, or among three growth forms (see Table S1) based on $\pi_{\mathrm{o}}, \pi_{\mathrm{t} \mid \mathrm{p}}, \varepsilon$ and $C_{\text {leaf. }}$.

Table 1. Stem and leaf hydraulic properties of four liana and five tree species in the present study. Values are means \pm S.E. $n=10-12$. MVL, maximum vessel length; $K_{\text {s-max }}$, maximum stem sapwood-specific conductivity $\left(\mathrm{kg} \mathrm{m}^{-1} \mathrm{~s}^{-1} \mathrm{MPa}^{-1}\right) ; P_{50}$, xylem water potential at $50 \%$ loss of hydraulic conductivity (MPa); PLC, percentage loss of conductivity (\%); midday $K_{s}$, midday stem sapwood-specific conductivity $\left(\mathrm{kg} \mathrm{m}^{-1} \mathrm{~s}^{-1} \mathrm{MPa}^{-1}\right) ; \pi_{o}$, osmotic potential at full turgor (MPa); $\pi_{t \mid p}$, leaf water potential at turgor loss point (MPa); $\varepsilon$, bulk modulus of elasticity (MPa); $C_{\text {leaf, }}$ absolute capacitance $\left(\mathrm{mol} \mathrm{m}^{-2} \mathrm{MPa}^{-1}\right)$. Different superscript letters represent significant difference at $P=0.05$. ND means no data available

\begin{tabular}{|c|c|c|c|c|c|c|c|c|c|c|c|}
\hline Species form & Growth & $\begin{array}{l}\text { Leaf } \\
\text { phen } \\
\text { ology }\end{array}$ & MVL & $\boldsymbol{K}_{s-\max }$ & $P_{50}$ & $\begin{array}{l}\text { Midday } \\
\text { PLC }\end{array}$ & $\begin{array}{l}\text { Midd } \\
\text { ay } K_{s}\end{array}$ & $\pi_{o}$ & $\pi_{\mathrm{t} \mid \mathrm{p}}$ & $\varepsilon$ & $C_{\text {leaf }}$ \\
\hline $\begin{array}{l}\text { Celastrus } \\
\text { paniculatus }\end{array}$ & Liana & D & 301 & $\begin{array}{l}8.62 \pm \\
1.6\end{array}$ & $-1 \cdot 42$ & $40 \cdot 91$ & $\begin{array}{l}7.97 \pm \\
1.8\end{array}$ & $\begin{array}{l}-1 \cdot 28 \\
\pm 0.2\end{array}$ & $\begin{array}{l}-1.57 \\
\pm 0.2\end{array}$ & $\begin{array}{l}14 \cdot 48 \\
\pm 2 \cdot 4\end{array}$ & $\begin{array}{l}0.85 \pm \\
0.1\end{array}$ \\
\hline $\begin{array}{l}\text { Marsdenia } \\
\text { sinensis }\end{array}$ & Liana & $E$ & 235 & $\begin{array}{l}10 \cdot 57 \\
\pm 1 \cdot 3\end{array}$ & -1.04 & $38 \cdot 27$ & $\begin{array}{l}3 \cdot 27 \pm \\
1 \cdot 2\end{array}$ & $\begin{array}{l}-0.97 \\
\pm 0.1\end{array}$ & $\begin{array}{l}-1.49 \\
\pm 0.1\end{array}$ & $\begin{array}{l}10.91 \\
\pm 1.4\end{array}$ & $\begin{array}{l}1.70 \pm \\
0.6\end{array}$ \\
\hline $\begin{array}{l}\text { Ventilago } \\
\text { calyculata }\end{array}$ & Liana & $E$ & 110 & $\begin{array}{l}4 \cdot 8 \pm \\
0.6\end{array}$ & $1 \cdot 57$ & 28.53 & $\begin{array}{l}7 \cdot 28 \pm \\
1 \cdot 0\end{array}$ & $\begin{array}{l}-2.02 \\
\pm 0.1\end{array}$ & $\begin{array}{l}-2.34 \\
\pm 0.1\end{array}$ & $\begin{array}{l}21.61 \\
\pm 2.4\end{array}$ & $\begin{array}{l}0.30 \pm \\
0.1\end{array}$ \\
\hline $\begin{array}{l}\text { Mucuna } \\
\text { interrupta }\end{array}$ & Liana & $\mathrm{E}$ & ND & ND & ND & ND & ND & $\begin{array}{l}-0.99 \\
\pm 0.1\end{array}$ & $\begin{array}{l}-1 \cdot 17 \\
\pm 0 \cdot 1\end{array}$ & $\begin{array}{l}7 \cdot 42 \pm \\
0.5\end{array}$ & $\begin{array}{l}0.12 \pm \\
0.0\end{array}$ \\
\hline Celtis tetrandra & Tree & $\mathrm{D}$ & 120 & $\begin{array}{l}6 \cdot 21 \pm \\
0.6\end{array}$ & -1.53 & $34 \cdot 67$ & $\begin{array}{l}4.61 \pm \\
0.7\end{array}$ & $\begin{array}{l}-1.96 \\
\pm 0.1\end{array}$ & $\begin{array}{l}-2.23 \\
\pm 0.0\end{array}$ & $\begin{array}{l}16.53 \\
\pm 1.9\end{array}$ & $\begin{array}{l}0.40 \pm \\
0.0\end{array}$ \\
\hline Ficus concinna & Tree & D & 61 & $\begin{array}{l}3.95 \pm \\
0.7\end{array}$ & -1.43 & $29 \cdot 55$ & $\begin{array}{l}2 \cdot 21 \pm \\
0 \cdot 8\end{array}$ & $\begin{array}{l}-1.63 \\
\pm 0.1\end{array}$ & $\begin{array}{l}-2.06 \\
\pm 0.1\end{array}$ & $\begin{array}{l}25 \cdot 81 \\
\pm 2 \cdot 0\end{array}$ & $\begin{array}{l}0.26 \pm \\
0.0\end{array}$ \\
\hline $\begin{array}{l}\text { Harpullia } \\
\text { cupanioides }\end{array}$ & Tree & $E$ & 192 & $\begin{array}{l}2 \cdot 2 \pm \\
0 \cdot 2\end{array}$ & $-2 \cdot 51$ & $15 \cdot 45$ & $\begin{array}{l}1.96 \pm \\
0.2\end{array}$ & $\begin{array}{l}-2.04 \\
\pm 0.1\end{array}$ & $\begin{array}{l}-2.37 \\
\pm 0.1\end{array}$ & $\begin{array}{l}16 \cdot 67 \\
\pm 1 \cdot 7\end{array}$ & $\begin{array}{l}0.49 \pm \\
0.0\end{array}$ \\
\hline $\begin{array}{l}\text { Michelia } \\
\text { hypolampra }\end{array}$ & Tree & $E$ & 74 & $\begin{array}{l}1.69 \pm \\
0.2\end{array}$ & $-2 \cdot 25$ & $24 \cdot 85$ & $\begin{array}{l}1 \cdot 13 \pm \\
0 \cdot 1\end{array}$ & $\begin{array}{l}-1.06 \\
\pm 0.1\end{array}$ & $\begin{array}{l}-1.40 \\
\pm 0.1\end{array}$ & $\begin{array}{l}11.0 \pm \\
1.5\end{array}$ & $\begin{array}{l}0.43 \pm \\
0.0\end{array}$ \\
\hline Streblus asper & Tree & $\mathrm{E}$ & 72 & $\begin{array}{l}1 \cdot 86 \pm \\
0 \cdot 4\end{array}$ & -2.93 & $14 \cdot 07$ & $\begin{array}{l}1.22 \pm \\
0.5\end{array}$ & $\begin{array}{l}-1.78 \\
\pm 0.0\end{array}$ & $\begin{array}{l}-2.26 \\
\pm 0.0\end{array}$ & $\begin{array}{l}15 \cdot 11 \\
\pm 0 \cdot 8\end{array}$ & $\begin{array}{l}0.55 \pm \\
0.0\end{array}$ \\
\hline Liana mean & & & $\begin{array}{l}215 \cdot 3 \\
3 \pm 56 \\
a\end{array}$ & $\begin{array}{l}8 \cdot 00 \pm \\
1 \cdot 7^{\mathrm{a}}\end{array}$ & $\begin{array}{l}-1.34 \\
\pm 0.2^{\mathrm{a}}\end{array}$ & $\begin{array}{l}35 \cdot 90 \pm \\
3 \cdot 8^{\mathrm{a}}\end{array}$ & $\begin{array}{l}6 \cdot 17 \pm \\
1 \cdot 5^{a}\end{array}$ & $\begin{array}{l}-1 \cdot 32 \\
\pm 0.3^{\mathrm{a}}\end{array}$ & $\begin{array}{l}-1 \cdot 64 \\
\pm 0 \cdot 2^{\mathrm{a}}\end{array}$ & $\begin{array}{l}13 \cdot 61 \\
\pm 3 \cdot 0^{\text {a }}\end{array}$ & $\begin{array}{l}0.74 \pm \\
0.4^{a}\end{array}$ \\
\hline Tree mean & & & $\begin{array}{l}103 \cdot 8 \\
0 \pm 24 \\
\cdot 3^{a}\end{array}$ & $\begin{array}{l}3 \cdot 18 \pm \\
0 \cdot 9^{b}\end{array}$ & $\begin{array}{l}-2 \cdot 13 \\
\pm 0 \cdot 3^{a}\end{array}$ & $\begin{array}{l}23 \cdot 72 \pm \\
4 \cdot 0^{a}\end{array}$ & $\begin{array}{l}2 \cdot 23 \pm \\
0 \cdot 6^{\mathrm{b}}\end{array}$ & $\begin{array}{l}-1.69 \\
\pm 0.2^{\mathrm{a}}\end{array}$ & $\begin{array}{l}-2 \cdot 06 \\
\pm 0.2^{b}\end{array}$ & $\begin{array}{l}17 \cdot 02 \\
\pm 2 \cdot 4^{a}\end{array}$ & $\begin{array}{l}0.43 \pm \\
0.0^{a}\end{array}$ \\
\hline
\end{tabular}

- Nomenclature follows Flora of China (http://foc.eflora.cn/). 

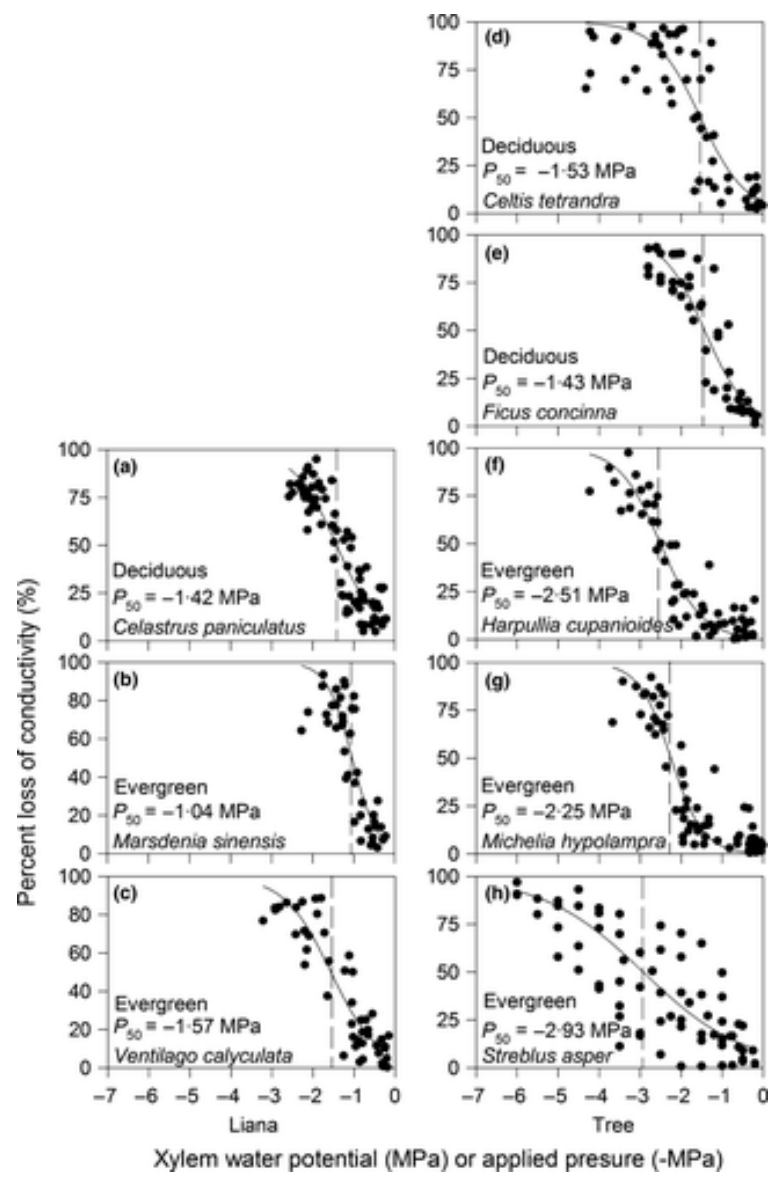

Figure 1 Stem vulnerability curves for three liana $(a-c)$ and five tree $(d-h)$ species. $P L C=$ the percentage loss of conductivity. $P<0.001$ for all regression lines. The vertical dashed lines indicate the xylem water potential at $50 \%$ loss of stem hydraulic conductivity $\left(P_{50}\right)$.

Daily water relations and native percentage loss of conductivity

The water potentials of sun-exposed leaves and stems declined in both liana and tree species during the daytime, with seven of the eight species losing their leaf turgor (Fig. 2); all species recovered overnight, however. At midday, lianas maintained higher daily minimal stem water potentials than trees (minimal $\Psi_{\text {stem }}$ in lianas: $-1.11 \pm 0.1 \mathrm{MPa}, n=4$ vs. in trees: $-1.62 \pm 0.2 \mathrm{MPa}, n=5 ; t=2.45, P<0.05)$, but midday leaf water potentials were comparable in lianas and trees (minimal $\Psi_{\text {leaf }}$ in lianas: $-2.48 \pm 0.6 \mathrm{MPa}, n=4$ vs. in trees: $-2.37 \pm 0.5 \mathrm{MPa}, n=5 ; t=-0.33, P=0.75)$. Differences between minimal leaf and stem water potentials $\left(\Delta \Psi_{\text {stem- }}\right.$ leaf) during the day were higher in lianas than tree species (lianas: 1.37 $\pm 0.2 \mathrm{MPa}, n=4$; trees:

$0.75 \pm 0.2 \mathrm{MPa}, n=5 ; t=2.5, P<0.05)$. Evergreen trees had lowest $\Delta \Psi_{\text {stem-leaf }}$ value among the three growth forms (see Table S1). 


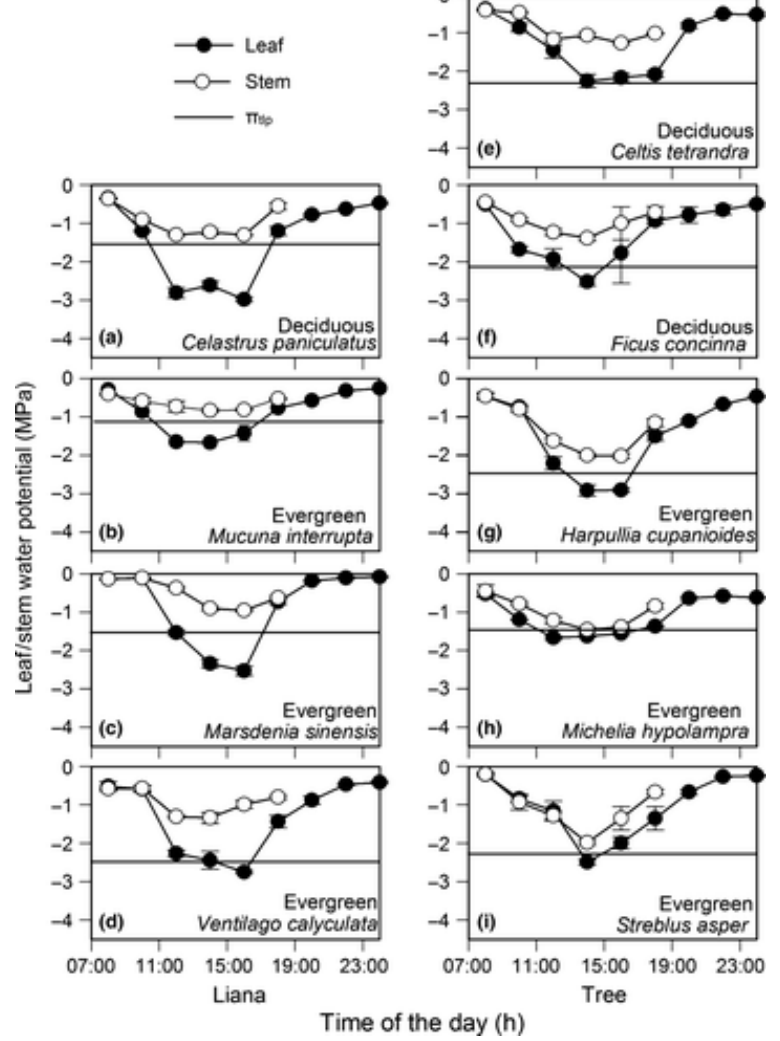

Figure 2 Diurnal variation in sun-exposed leaf and stem water potentials for four liana $(a-d)$ and five tree (e-i) species. Values are means $\pm \mathrm{SE}, n=6$. The solid lines represent leaf turgor loss point $\left(\pi_{\mathrm{tlp}}\right)$.

Seven of the eight species had higher PLC at midday than at pre-dawn (Fig. $\underline{3}$ ). Although the mean value of midday PLC for lianas was much greater than trees (Table 1 ), these were only marginally significant $(P=0.087)$. Specifically, the three liana species (ranging from $28.5 \%$ for $V$. calyculata to $40.9 \%$ in C. paniculatus) and two deciduous trees (ranging from $29.6 \%$ for $F$. concinna to $34.7 \%$ for $C$. terandra) had relatively greater PLC at midday than did the three evergreen tree species (ranging from $14.1 \%$ for S. asper to $24.9 \%$ for M. hypolampra; see Table S1). However, lianas still exhibited significantly greater conductivity than trees at midday (midday $K_{s}$ : in lianas: $6 \cdot 17 \pm 1.5 \mathrm{~kg} \mathrm{~m}^{-1} \mathrm{~s}^{-1} \mathrm{MPa}^{-1}, n=3$; in trees: $2 \cdot 23 \pm 0.6 \mathrm{~kg} \mathrm{~m}^{-1} \mathrm{~s}^{-1} \mathrm{MPa}^{-1}, n=5 ; t=2 \cdot 9, P=0.027$ ).

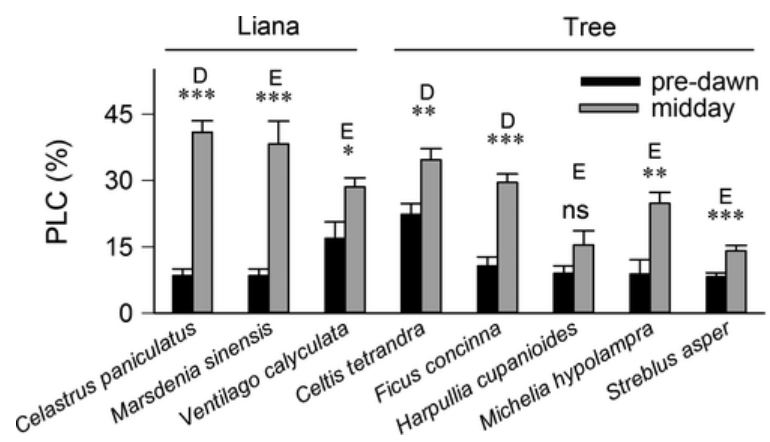

Figure 3 The native percentage loss of conductivity (PLC) in three liana and four tree species. Values are mean \pm SE. $n=10$. ${ }^{\text {ns }} P>0.05 ;{ }^{*} P<0.05 ; * * P<0.01 ; * * * P<0.001 ; \mathrm{D}$, deciduous; $\mathrm{E}$, evergreen.

Diurnal variances in leaf photosynthesis and stomatal conductance

Both lianas and trees reached maximal photosynthesis at 10:00-11:00 (with the exception of $V$. calyculata and M. hypolampra, both of which peaked between 12:00 and 13:00; Fig. 4). With increasing 
VPD, photosynthetic rates of both lianas and trees decreased rapidly in late morning or early afternoon. However, all liana species exhibited a sustained decline in photosynthesis until dark, whereas a slow decrease (Fig. $\underline{4 g}$, i) or even a slight increase in the early afternoon (Fig. 4 e, h) was observed in four of five tree species. Leaf stomatal conductance of lianas was high before 10:00, then decreased and remained low in the afternoon (Fig. $\underline{4} a-d)$; the stomata of one liana species, M. interrupta, were almost entirely closed during the afternoon (Fig. $4 \mathrm{~b}$ ). In contrast, three of five trees species exhibited a slight increase in $g_{\mathrm{s}}$ during the period 14:00-16:00 (Fig. $\underline{\mathbf{4}} \mathrm{f}-\mathrm{h}$ ). Surprisingly, no differences in leaf-level water-use efficiency were observed between lianas and trees over the course of the day, with the exception of the 10:00 period (see Fig. S2).

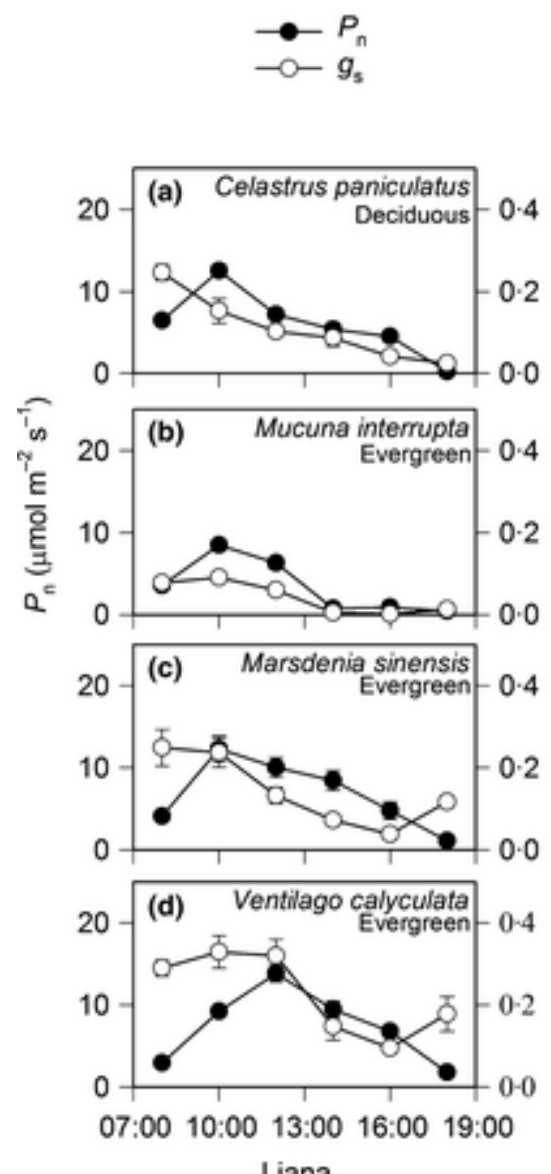

Time of the day $(\mathrm{h})$
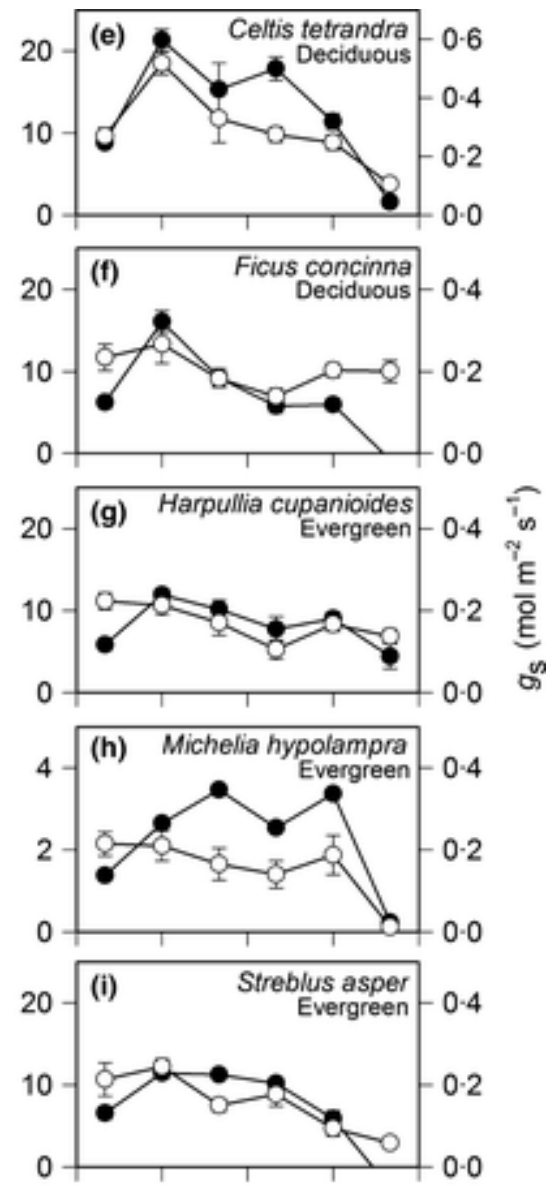

07:00 10:00 13:00 16:00 19:00

Tree

Figure 4 Diurnal variation in photosynthetic rate $\left(P_{n}\right)$ and stomatal conductance $\left(g_{\mathrm{s}}\right)$ for four liana (a-d) and five tree (e-i) species. Values are means $\pm \mathrm{SE}, n=6$. Note the different axial scales in (e) and (h).

\section{Dynamics of sap flow}

Mean maximal PPFD and VPD were approximately $1500 \mu \mathrm{mol} \mathrm{m} \mathrm{m}^{-2} \mathrm{~s}^{-1}$ and $3 \mathrm{kPa}$, respectively, during the sap-flow measurement period (Fig. $\underline{5}$ a), with a 3-h time lag between maximum PPFD and VPD (PPFD peaked at 12:00, VPD peaked at 15:00). Liana species reached maximum sap flow faster than trees (Fig. $\underline{5} b ;$ Table S2); sap flow was initiated at around 9:00 and reached peak sap flow $\left(80 \% J_{\max }\right)$ at around 10:50 in lianas, whereas trees initiated sap flow at around 9:50 and reached peak sap flow at around 12:20 (see Table S2). Thus, liana species quickly reached peak sap flow earlier (when VPD was close to $1 \mathrm{kPa}$ ) and sustained it for a longer period of time than tree species; in trees, sap flow tended to begin to decline immediately following peak flow (Fig. $\underline{5}$ b). Liana species had 1.7 times greater mean $J_{\max }$ than trees $(P<0.01$, Fig. $\underline{5}$ b; Table S2). 


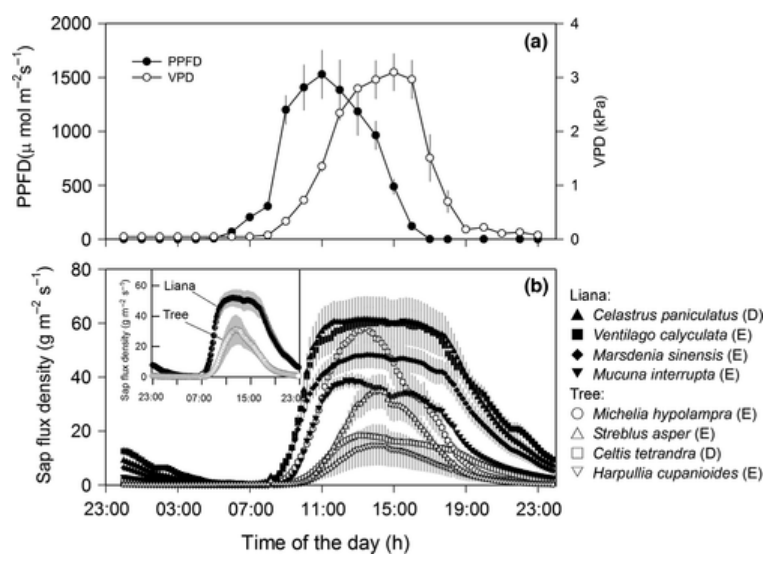

Figure 5 Diurnal variation in photosynthetic photon flux density (PPFD), vapour pressure deficit (VPD) (a), and in sap flux density (b) of four liana and four tree species. Values are means \pm SE for each species over four clear days during the period 8-21 October 2012. Inset figure shows mean $J_{s} \pm S E$ of lianas and trees. $D$, deciduous; $E$, evergreen.

\section{Stomatal conductance and sap flow in relation to water status and VPD}

Our mixed-model analysis comparing stomatal conductance in trees and lianas against leaf water potential, xylem water potential and VPD indicated that $g_{\mathrm{s}}$ in both liana and tree species decreased with decreasing $\Psi_{\text {leaf }}$ and $\Psi_{\text {stem }}$ and decreased with increasing VPD (Fig. $\underline{6}$ ), but that there were no significant differences between lianas and trees in the responsiveness of stomatal conductance for these parameters based on gas exchange data (Fig. $\underline{6}$; Table S3). However, we observed that the $J_{s}$ of lianas increased at a quicker rate with increasing VPD than that of trees when VPD $<1 \mathrm{kPa}$ (Fig. ㄱ).
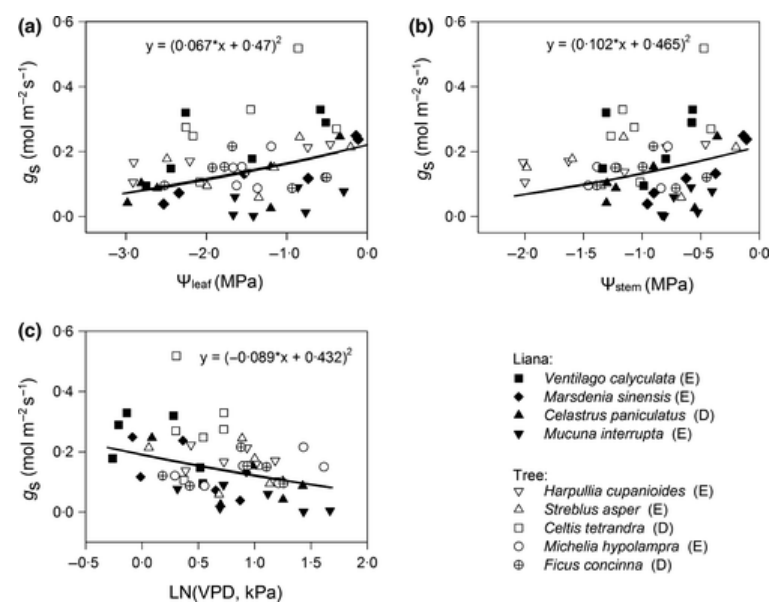

Figure 6 The relationships of leaf stomatal conductance $\left(g_{s}\right)$ with leaf $\left(\Psi_{\text {leaf }}\right.$, a) and xylem $\left(\Psi_{\text {stem, }}, \mathrm{b}\right)$ water potential and vapour pressure deficits (VPDs, c) in four liana and five tree species. Values are means for each species over four clear days during the period 8-21 October 2012. D, deciduous; E, evergreen. Results of mixed model (see Table S3) showed that there were no significant differences in slopes and intercepts in the responsiveness of $g_{\mathrm{s}}$ to $\Psi_{\text {leaf }} \Psi_{\text {stem }}$ and VPD between lianas and trees. 


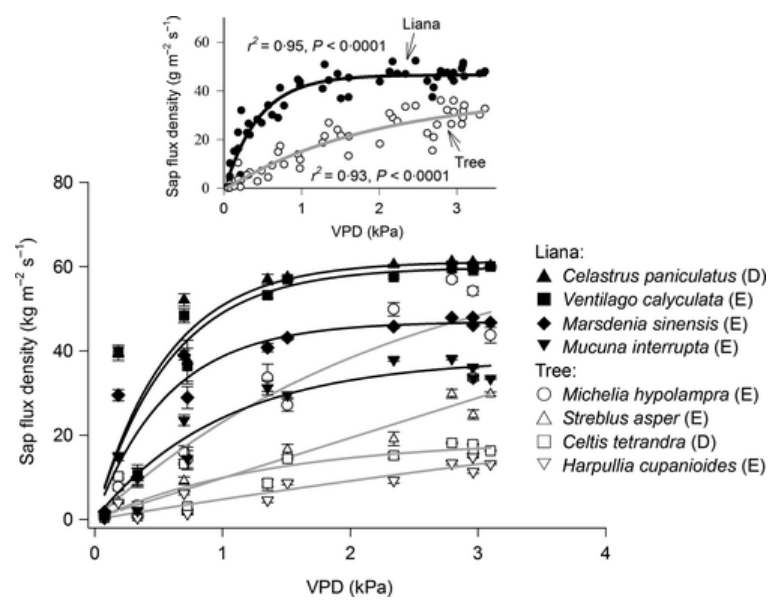

Figure 7 The response of sap flux density $\left(J_{s}\right)$ to increasing vapour pressure deficits (VPDs, $\mathrm{kPa}$ ) during the daytime (8:00-19:00) over four clear days during the period 8-21 October 2012. Values are means \pm SE of hourly averages of each species. Inset figure shows the relationship between mean $J_{s} \pm$ SE and VPDs in lianas $(n=4)$ and trees $(n=4)$. Data were fitted using a two-parameter exponential function as: $y=\mathrm{a} \times(1-\exp (-\mathrm{b} \times x)) . P<0.001$ for all regression lines. $D$, deciduous; $E$, evergreen.

\section{Discussion}

Lianas seem to deploy a more 'risky' hydraulic strategy in terms of their high stem sapwood-specific conductivity and corresponding susceptibility to embolism, which is consistent with previous research on juveniles (van der Sande et al. 2013) and mature (Zhu \& Cao 2009; Johnson et al. 2013) individuals. Evergreen trees had a particularly conservative hydraulic strategy compared to both lianas and deciduous trees, whereas liana and the deciduous tree species were more susceptible to drought-induced cavitation than the evergreen trees, as indicated by their lower negative $P_{50}$ and higher midday PLC values. However, lianas also tended to have higher stem sapwood-specific conductivity than did the co-occurring trees, conferring lianas with greater water transport efficiency. Thus, despite losing up to nearly half of their conductivity at midday (i.e. midday PLC ranging from $28.5 \%$ in V. calyculata to $40.9 \%$ in C. paniculatus), lianas were able to continue to transport water efficiently to the canopy during the afternoon. The larger degree of interspecific variance and limited number of species included in this study resulted in non-significant differences between the lianas and trees in regard to many parameters (e.g. MVL, $P_{50}$, midday PLC and P-V curve), and therefore, such findings must be validated by future research using a far larger range of species.

Deciduous tree species had similar hydraulic properties as lianas, suggesting that lianas and deciduous trees may share similar water-use strategies for dealing with water deficits. Root pressure may be a driving force for refilling diurnally dysfunctional vessels, especially in monocots (Cao et al. 2012; Yang et al. 2012). Until now, there has been no convincing empirical evidence that lianas can refill emboli in conduits solely using root pressure, given that in most lianas, species root pressure alone is insufficient for refilling gas-filled vessels in the upper stems (Ewers, Cochard \& Tyree 1997; Tibbetts \& Ewers 2000). Further studies are needed to test whether cavitation occurs during the day and how the refilled conduits are able to reconnect to functional conduits (Rockwell et al. 2014).

In this study, sun-exposed leaf water potentials of all species reached or were close to their turgor loss points, implying possible leaf wilting and stomatal closure, which slowing further water loss. However, lianas lost leaf turgor earlier (about $2 \mathrm{~h}$ ) than trees, which may be attributed to their earlier exposure to light than trees, as the majority of liana leaves are at the top of the canopy. The ability of lianas to close their stomata rapidly in response to declining leaf or stem water potential allows them to reduce water consumption under conditions 
of high VPD, giving them an advantage in terms of maintaining stem water potential. Moreover, the higher stem water potential despite comparable leaf water potential in lianas at midday compared to trees probably benefit from their efficient water transport. Lianas tend to have higher stem sapwood-specific conductivity and trunk (main stem) maximum sap flux density than do co-occurring trees owing to a comparatively well-developed vessel system (e.g. wide and long vessels); lianas are thus able to supply far more water to their leaves per active xylem area than trees are. Furthermore, the ability to efficiently transport water from the soil to the stems via their deep roots (Restom \& Nepstad 2004) may help lianas buffer daytime water loss by transpiration because they are considered to have deep roots (Chen et al. 2015).

Liana species initiated and reached peak sap flow faster and earlier than trees, suggesting that lianas may be more reliant to on water transported from the soil rather than water stored in stems. Therefore, there are short time lags between basal sap flow and canopy transpiration in lianas, whereas in trees, in contrast, the gradual and slow increase in sap flow despite high canopy transpiration (high $g_{s}$ ) in the morning ( 10:00) suggests substantial buffering from the internal water-storage pool. This contrasting sap-flow pattern between lianas and trees has been demonstrated in previous studies (Phillips et al. 1999; Chen et al. 2015, 2016a). Tropical trees differ in the size of their internal water storage, with some large trees providing substantial amounts of water to the transpiration stream; for example, a study of canopy trees in Panama found that the amount of water withdrawn from stem water storage and used to replace transpirational water losses range from $4 \mathrm{~kg} \mathrm{day}^{-1}$ to $54 \mathrm{~kg} \mathrm{day}^{-1}$ daily, depending on the main stem size, representing $9-15 \%$ of a tree's total daily water loss (Goldstein et al. 1998).

At the leaf level, lianas and co-occurring trees exhibited similar responsiveness of stomatal conductance to increasing VPD and coupled decreasing leaf or stem water potential during the day; these findings were not aligned with those for the whole-plant sap-flow data. Obviously, lianas reached maximum transpiration at a relative low VPD $(<1 \mathrm{kPa})$ than did trees; in contrast, trees conformed to a near-linear increase of transpiration against increasing VPD. This inconsistency between leaf and whole-plant performance may be partly attributed to the fact that only a few sun-exposed leaves were included in the canopy gas exchange analyses; on the other hand, it is possible that the gas exchange system could not fully match the ambient and within-cuvette VPDs, specifically when under high transpirational demand in the canopy.

The earlier, high level of transpiration in lianas potentially indicates their vigorous carbon fixation during the morning hours. Lianas are believed to be capable of ramping up photosynthesis more rapidly than trees due to their larger investment in photosynthetic chemistry (e.g. higher mass-based photosynthetic pigments, N and P; Asner \& Martin 2012). This physiological adaptation may be an essential feature of lianas given the unequal distribution of their leaves, with most occurring at the top of the canopy where they are exposed to sunlight, wind and high temperatures throughout the day; in contrast, only the top leaves of the co-occurring trees are sunlit, and much of the rest of the canopy is sheltered by the upper leaves of the trees and their liana competitors. The vertical distribution of tree leaves may allow them to utilize a spatial segmentation strategy, wherein the top exposed leaves fix carbon in the morning when VPD is low, and the shaded leaves can fix carbon later in the day, when most sun-exposed canopy leaves are downregulated under direct light and high VPD.

The constantly high transpiration in lianas as a result of higher transpirational demand ( $>1 \mathrm{kPa})$ may be attributed to the sharp decline in stomatal conductance in the afternoon due to stomata closure. The wholeplant transpiration may remain high even as $g_{s}$ decreases as a consequence of rising VPD. Thus, stomatal closure may permit lianas to maintain high and steady transpiration rates with increasing VPD, especially early in the day, which may also help lianas reduce water loss during the dry season when soil water is limited (Chen et al. 2015). 


\section{Conclusions}

Lianas appear to have low water-storage capacity and are vulnerable to drought-induced cavitation due to their wide vessels and slim stems. However, physiological regulation (stomatal closure) and efficient water transport from the soil to terminal branches (high stem sapwood-specific conductivity and sap flux density) may help lianas maintain stem water potential within the safe range to avoid xylem dysfunction. Physiological regulation may be particularly important for lianas, which tend to deploy the majority of their leaves at the top of the forest canopy, where they flourish despite the trifecta of high light intensity, temperatures and windiness - all of which increase VPD and thus water stress. Our results therefore provide a potential physiological explanation of how lianas can have large vascular systems, which permit them to transport copious amounts of water and yet still avoid catastrophic hydraulic failure and thrive in tropical forest canopies. However, further research involving more species is needed to determine whether these physiological adaptations are common among lianas.

\section{Acknowledgements}

We thank Hong Ma, Xue-Wei Fu, Wan-li Zhao and Qiu-Yun Yang for assistance with the field work, Bin Wen for species identification and three anonymous reviewers and editors for their helpful comments to improve the earlier version of this manuscript. The Xishuangbanna Station for Tropical Rain Forest Ecosystem Studies provided the climatic data. This work was financially supported by the National Natural Science Foundation of China (No. 31570406, 31100291), CAS 'Light of West China' Program and Youth Innovation Promotion Association CAS (No. 2016351) to YJC and the Applied Fundamental Research Program of Yunnan Province (2013FB078).

\section{Data accessibility}

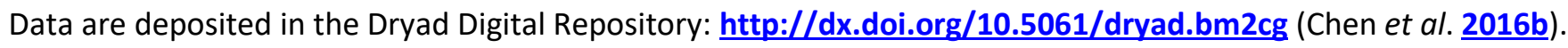

\section{Supporting Information}

\begin{tabular}{|c|c|}
\hline Filename & Description \\
\hline $\begin{array}{l}\frac{\text { fec12724-sup-0001- }}{230.2 \mathrm{~KB}} \\
\text { LaySummary.pdfPDF document, }\end{array}$ & Lay Summary \\
\hline$\frac{\text { fec12724-sup-0002- }}{\frac{\text { AppendixS1.docWord document, }}{48.5 \mathrm{~KB}}}$ & Appendix S1. Vulnerability curve measurements. \\
\hline$\frac{\text { fec12724-sup-0003-FigS1- }}{\underline{\text { 2.docWord document, 1.5 MB }}}$ & $\begin{array}{l}\text { Fig. } \mathbf{S 1} \text {. The change of xylem water potential at } 30 \text {-min intervals during the } \\
\text { first } 2 \mathrm{~h} \text { rehydration in Celastrus paniculatus and Ventilago calyculata. } \\
\text { Fig. S2. Diurnal variation in leaf water-use efficiency (WUE) for four liana } \\
\text { and five tree species. }\end{array}$ \\
\hline$\frac{\text { fec12724-sup-0004-TableS1- }}{\text { 3.docWord document, } 85 \mathrm{~KB}}$ & $\begin{array}{l}\text { Table S1. Mean stem and leaf hydraulic properties of the three growth } \\
\text { forms (lianas, deciduous trees and evergreen trees) and results } \\
\text { of anova testing for differences between the growth forms. } \\
\text { Table S2. Sap-flow characteristics of four liana and four tree species. } \\
\text { Table S3. Results of mixed-models examining the relationships between } \\
\left.\text { stomatal conductance }\left(g_{s}\right) \text { and leaf water potential ( } \Psi_{\text {leaf }}\right) \text {, xylem water } \\
\text { potential }\left(\Psi_{\text {stem }}\right) \text { and VPD in trees and lianas. }\end{array}$ \\
\hline
\end{tabular}

Please note: The publisher is not responsible for the content or functionality of any supporting information supplied by the authors. Any queries (other than missing content) should be directed to the corresponding author for the article. 


\section{References}

Asner, G.P. \& Martin, R.E. ( 2012) Contrasting leaf chemical traits in tropical lianas and trees: implications for future forest composition. Ecology Letters, 15, 1001- 1007.

Bates, D., Maechler, M., Bolker, B. \& Walker, S. ( 2015) Fitting linear mixed-effects models using Ime4. Journal of Statistical Software, 67,1- 48.

Brodribb, T.J. \& Holbrook, N.M. ( 2003) Stomatal closure during leaf dehydration, correlation with other leaf physiological traits. Plant Physiology, 132, 2166- 2173.

Brodribb, T.J. \& Holbrook, N.M. ( 2004) Diurnal depression of leaf hydraulic conductance in a tropical tree species. Plant, Cell \& Environment, 27, 820- 827.

Brodribb, T.J., Holbrook, N.M., Edwards, E.J. \& Gutierrez, M.V. ( 2003)Relations between stomatal closure, leaf turgor and xylem vulnerability in eight tropical dry forest trees. Plant, Cell \& Environment, 26, 443- 450.

Bucci, S.J., Scholz, F.G., Goldstein, G., Meinzer, F.C. \& Sternberg, L.D.L.( 2003) Dynamic changes in hydraulic conductivity in petioles of two savanna tree species: factors and mechanisms contributing to the refilling of embolized vessels. Plant, Cell \& Environment, 26, 1633- 1645.

Bunce, J.A. ( 2006) How do leaf hydraulics limit stomatal conductance at high water vapour pressure deficits? Plant, Cell \& Environment, 29,1644- 1650.

Cao, K.F., Yang, S.J., Zhang, Y.J. \& Brodribb, T.J. ( 2012) The maximum height of grasses is determined by roots. Ecology Letters, 15, 666- 672.

Chapotin, S.M., Razanameharizaka, J.H. \& Holbrook, N.M. ( 2006)Water relations of baobab trees (Adansonia spp. L.) during the rainy season: does stem water buffer daily water deficits? Plant, Cell \& Environment, 29, 1021- 1032.

Chave, J., Riera, B. \& Dubois, M.A. ( 2001) Estimation of biomass in a neotropical forest of French Guiana: spatial and temporal variability. Journal of Tropical Ecology, 17, 79- 96.

Chen, Y.J., Bongers, F., Zhang, J.L., Liu, J.Y. \& Cao, K.F. ( 2014) Different biomechanical design and ecophysiological strategies in juveniles of two liana species with contrasting growth habit. American Journal of Botany, 101, 925- 934.

Chen, Y.J., Cao, K.F., Schnitzer, S.A., Fan, Z.X., Zhang, J.L. \& Bongers, F.( 2015) Water-use advantage for lianas over trees in tropical seasonal forests. New Phytologist, 205, 128- 136.

Chen, Y.J., Bongers, F., Tomlinson, K., Fan, Z.X., Lin, H., Zhang, S.B.et al. ( 2016a) Time lags between crown and basal sap flows in tropical lianas and co-occurring trees. Tree Physiology, 36, 736- 747.

Chen, Y., Schnitzer, S.A., Zhang, Y., Fan, Z., Goldstein, G., Tomlinson, K.W., et al. ( 2016b) Data from: Physiological regulation and efficient xylem water transport regulate diurnal water and carbon balances of tropical lianas. Dryad Digital Repository. http://dx.doi.org/10.5061/dryad.bm2cg.

Cochard, H., Cruiziat, P. \& Tyree, M.T. ( 1992) Use of positive pressures to establish vulnerability curves. Plant Physiology, 100,205- 209.

Cochard, H. \& Delzon, S. ( 2013) Hydraulic failure and repair are not routine in trees. Annals of Forest Science, 70, 659-661.

Comstock, J. \& Mencuccini, M. ( 1998) Control of stomatal conductance by leaf water potential in Hymenoclea salsola (T \& G), a desert subshrub. Plant, Cell \& Environment, 21, 1029- 1038.

Ewers, F.W., Cochard, H. \& Tyree, M.T. ( 1997) A survey of root pressures in vines of a tropical lowland forest. Oecologia, 110, 191- 196.

Ewers, F.W. \& Fisher, J.B. ( 1989) Techniques for measuring vessel lengths and diameters in stems of woodyplants. American Journal of Botany, 76, 645- 656.

Gerwing, J.J. \& Farias, D.L. ( 2000) Integrating liana abundance and forest stature into an estimate of total aboveground biomass for an eastern Amazonian forest. Journal of Tropical Ecology, 16, 327- 335.

Goldstein, G., Andrade, J.L., Meinzer, F.C., Holbrook, N.M., Cavelier, J., Jackson, P. et al. ( 1998) Stem water storage and diurnal patterns of water use in tropical forest canopy trees. Plant, Cell \& Environment,21, 397-406.

Granier, A. ( 1987) Evaluation of transpiration in a Douglas-Fir stand by means of sap flow measurements. Tree Physiology, 3, 309- 319. 
Hacke, U.G. ( 2014) Variable plant hydraulic conductance. Tree Physiology, 34, 105- 108.

Isnard, S. \& Silk, W.K. ( 2009) Moving with climbing plants from Charles Darwin's time into the 21st century. American Journal of Botany, 96, 1205- 1221.

Johnson, D.M., McCulloh, K.A., Meinzer, F.C., Woodruff, D.R. \& Eissenstat, D.M. ( 2011) Hydraulic patterns and safety margins, from stem to stomata, in three eastern US tree species. Tree Physiology,31, 659- 668.

Johnson, D.M., Domec, J.C., Woodruff, D.R., McCulloh, K.A. \& Meinzer, F.C. ( 2013) Contrasting hydraulic strategies in two tropical lianas and their host trees. American Journal of Botany, 100, 374- 383.

Ledo, A. \& Schnitzer, S.A. ( 2014) Disturbance and clonal reproduction determine liana distribution and maintain liana diversity in a tropical forest. Ecology, 95, 2169- 2178.

Lenz, T.I., Wright, I.J. \& Westoby, M. ( 2006) Interrelations among pressure-volume curve traits across species and water availability gradients. Physiologia Plantarum, 127, 423- 433.

McDowell, N., Pockman, W.T., Allen, C.D., Breshears, D.D., Cobb, N., Kolb, T. et al. ( 2008) Mechanisms of plant survival and mortality during drought: why do some plants survive while others succumb to drought? New Phytologist, 178, 719- 739.

Phillips, N., Oren, R., Zimmermann, R. \& Wright, S.J. ( 1999) Temporal patterns of water flux in trees and lianas in a Panamanian moist forest. Trees-Structure and Function, 14, 116- 123.

Putz, F.E. ( 1983) Liana biomass and leaf-area of a Tierra Firme Forest in the Rio-Negro Basin, Venezuela. Biotropica, 15, 185- 189.

Restom, T.G. \& Nepstad, D.C. ( 2004) Seedling growth dynamics of a deeply rooting liana in a secondary forest in eastern Amazonia. Forest Ecology and Management, 190, 109-118.

Rockwell, F.E., Wheeler, J.K. \& Holbrook, N.M. ( 2014) Cavitation and its discontents: opportunities for resolving current controversies. Plant Physiology, 164, 1649- 1660.

Sack, L., Pasquet-Kok, J. \& contributors, P. ( 2011) Leaf pressure-volume curve parameters. PrometheusWiki, http://prometheuswiki.publish.csiro.au/tiki-index.php?page=Leaf+pressurevolume+curve+parameters.

Salleo, S., Nardini, A., Pitt, F. \& Lo Gullo, M.A. ( 2000) Xylem cavitation and hydraulic control of stomatal conductance in Laurel (Laurus nobilis L.). Plant, Cell \& Environment, 23, 71- 79.

van der Sande, M.T., Poorter, L., Schnitzer, S.A. \& Markesteijn, L. ( 2013) Are lianas more drought-tolerant than trees? A test for the role of hydraulic architecture and other stem and leaf traits. Oecologia, 172, 961-972.

Schnitzer, S.A. ( 2005) A mechanistic explanation for global patterns of liana abundance and distribution. American Naturalist, 166, 262- 276.

Schnitzer, S.A. \& Bongers, F. ( 2002) The ecology of lianas and their role in forests. Trends in Ecology \& Evolution, 17, 223- 230.

Schnitzer, S.A. \& Bongers, F. ( 2011) Increasing liana abundance and biomass in tropical forests: emerging patterns and putative mechanisms. Ecology Letters, 14, 397- 406.

Scoffoni, C. \& Sack, L. ( 2015) Are leaves "freewheelin"? Testing for a Wheeler-type effect in leaf xylem hydraulic decline. Plant, Cell \& Environment, 38, 534- 543.

Scoffoni, C., McKown, A.D., Rawls, M. \& Sack, L. ( 2012) Dynamics of leaf hydraulic conductance with water status: quantification and analysis of species differences under steady state. Journal of Experimental Botany, 63, 643- 658.

Simonin, K.A., Burns, E., Choat, B., Barbour, M.M., Dawson, T.E. \& Franks, P.J. ( 2015) Increasing leaf hydraulic conductance with transpiration rate minimizes the water potential drawdown from stem to leaf. Journal of Experimental Botany, 66, 1303- 1315.

Sperry, J.S., Donnelly, J.R. \& Tyree, M.T. ( 1988) A method for measuring hydraulic conductivity and embolism in xylem. Plant, Cell \& Environment, 11, 35- 40.

Tibbetts, T.J. \& Ewers, F.W. ( 2000) Root pressure and specific conductivity in temperate lianas: exotic Celastrus orbiculatus(Celastraceae) vs. native Vitis riparia (Vitaceae). American Journal of Botany, 87, 1272- 1278.

Torres-Ruiz, J.M., Cochard, H., Mayr, S., Beikircher, B., Diaz-Espejo, A., Rodriguez-Dominguez, C.M. et al. (2014) Vulnerability to cavitation in Olea europaea current-year shoots: further evidence of an open- 
vessel artifact associated with centrifuge and air-injection techniques. Physiologia

Plantarum, 152, 465-474.

Torres-Ruiz, J.M., Jansen, S., Choat, B., McElrone, A.J., Cochard, H., Brodribb, T.J. et al. ( 2015) Direct X-Ray microtomography observation confirms the induction of embolism upon xylem cutting under tension. Plant Physiology, 167, 40- 43.

Trifilò, P., Raimondo, F., Gullo, M.A.L., Barbera, P.M., Salleo, S. \& Nardini, A. ( 2014) Relax and refill: xylem rehydration prior to hydraulic measurements favours embolism repair in stems and generates artificially low PLC values. Plant, Cell \& Environment, 37,2491- 2499.

Tucci, M.L.S., Erismann, N.M., Machado, E.C. \& Ribeiro, R.V. ( 2010)Diurnal and seasonal variation in photosynthesis of peach palms grown under subtropical conditions. Photosynthetica, 48, 421- 429.

Venturas, M.D., MacKinnon, E.D. \& Jacobsen, A.L. ( 2014) Excising stem samples under water at native tension does not induce xylem cavitation. Plant, Cell \& Environment, 38, 1060- 1068.

Wang, R.Q., Zhang, L., Zhang, S., Cai, J. \& Tyree, M.T. ( 2014) Water relations of Robinia pseudoacacia L.: do vessels cavitate and refill diurnally or are R-shaped curves invalid in Robinia? Plant, Cell \& Environment, 37, 2667- 2678.

Wheeler, J.K., Huggett, B.A., Tofte, A.N., Rockwell, F.E. \& Holbrook, N.M. ( 2013) Cutting xylem under tension or supersaturated with gas can generate $P L C$ and the appearance of rapid recovery from embolism. Plant, Cell \& Environment, 36, 1938- 1949.

Wyka, T.P., Oleksyn, J., Karolewski, P. \& Schnitzer, S.A. ( 2013)Phenotypic correlates of the lianescent growth form: a review. Annals of Botany, 112, 1667- 1681.

Yang, S.J., Zhang, Y.J., Sun, M., Goldstein, G. \& Cao, K.F. ( 2012)Recovery of diurnal depression of leaf hydraulic conductance in a subtropical woody bamboo species: embolism refilling by nocturnal root pressure. Tree Physiology, 32, 414- 422.

Zhang, Y.J. \& Holbrook, N.M. ( 2014) The stability of xylem water under tension: a long, slow spin proves illuminating. Plant, Cell \& Environment, 37, 2652- 2653.

Zhang, Y.J., Meinzer, F.C., Qi, J.H., Goldstein, G. \& Cao, K.F. ( 2013)Midday stomatal conductance is more related to stem rather than leaf water status in subtropical deciduous and evergreen broadleaf trees. Plant, Cell \& Environment, 36, 149- 158.

Zhu, S.D. \& Cao, K.F. ( 2009) Hydraulic properties and photosynthetic rates in co-occurring lianas and trees in a seasonal tropical rainforest in southwestern China. Plant Ecology, 204, 295- 304.

Zufferey, V., Cochard, H., Ameglio, T., Spring, J.L. \& Viret, O. ( 2011)Diurnal cycles of embolism formation and repair in petioles of grapevine (Vitis vinifera cv. Chasselas). Journal of Experimental Botany,62, 3885- 3894. 